\title{
Chemical characteristics of the snow pits at Murododaira, Mount Tateyama, Japan
}

\author{
Koichi WATANABE, ${ }^{1}$ Yukiko SAITO, ${ }^{1}$ Syoko TAMURA, ${ }^{1}$ Yuki SAKAI, ${ }^{1}$ Nagisa EDA, ${ }^{1}$ \\ Mikiko AOKI, ${ }^{1}$ Manami KAWABUCHI, ${ }^{1}$ Hirotsugu YAMADA, ${ }^{1}$ Ayumi IWAI, ${ }^{1}$ \\ Kunio KAWADA ${ }^{2}$ \\ ${ }^{1}$ Toyama Prefectural University, 5180 Kurokawa, Imizu, Toyama 939-0398, Japan \\ E-mail: nabe@pu-toyama.ac.jp \\ ${ }^{2}$ University of Toyama, 3190 Gofuku, Toyama 930-8555, Japan
}

\begin{abstract}
Measurements of the chemical composition of the snow pits at Murododaira $(2450 \mathrm{~m}$ a.s.I.), Mount Tateyama, near the coast of the Japan Sea in central Japan, were performed each spring from 2005 through 2008. The mean concentrations of $\mathrm{nssSO}_{4}{ }^{2-}$ and $\mathrm{NO}_{3}{ }^{-}$are higher than those in snowpack in the 1990s. The $\mathrm{pH}$ and $\mathrm{nssCa}^{2+}$ were usually high in the upper parts of $2-3 \mathrm{~m}$ of snow deposited in the spring, when Asian dust (Kosa) particles are frequently transported. High concentrations of nssSO ${ }_{4}{ }^{2-}$ were detected in both the spring and winter layers. The high-nssCa ${ }^{2+}$ layers usually contained high concentrations of $\mathrm{nssSO}_{4}{ }^{2-}$. The results show that not only Kosa particles but also air pollutants might have been transported long-range from the continent of Asia. The concentrations of peroxides were high in the new snow (precipitation particles) and granular snow (coarse grain, melt forms) layers. The peroxide concentrations in the snow layers were negatively correlated with the nssCa ${ }^{2+}$ concentrations. High peroxide concentrations may be preserved in granular snow layers having low concentrations of $\mathrm{nssCa}^{2+}$.
\end{abstract}

\section{INTRODUCTION}

The rapid growth of industry in East Asia is associated with high anthropogenic emissions of pollutants. Pollutants from the Asian continent may be actively transported to the atmosphere over the Japan Sea (Hatakeyama and others, 2001; Watanabe and others, 2001a). The air pollutants promote cloud and precipitation water acidification and affect the microphysical properties of the clouds (Watanabe and others, 2001a). Recently, a large amount of acidic species (e.g. non-sea-salt sulfate) has been deposited in the Hokuriku District, along the Japan Sea coast in central Japan (Honoki and others, 2001, 2007). In addition to pollutants, mineral Asian dust particles (Kosa in Japanese), rich in $\mathrm{CaCO}_{3}$, are also transported from the Asian continent (Tsuruta, 1991; Watanabe and others, 2006c). Kosa particles not only affect the radiation intensity in the atmosphere, but also contribute to neutralization of acid in water droplets (Watanabe and others, 1999; Watanabe and Honoki, 2003). The oxidative capacity in the atmosphere may also become high over East Asian countries, including Japan. Ozone $\left(\mathrm{O}_{3}\right)$ concentrations in the background troposphere have significantly increased (Akimoto and others, 1994). According to Tanimoto (2009), an increase of about $1 \mathrm{ppba}^{-1}$ in the average concentration of $\mathrm{O}_{3}$ was observed from 1998 to 2006 over Japan, especially in the spring, when background $\mathrm{O}_{3}$ shows maximum concentrations in the middle to high latitudes (Watanabe and others, 2005b). The increase in $\mathrm{O}_{3}$ may accelerate the formation of peroxides (hydrogen peroxide $\left(\mathrm{H}_{2} \mathrm{O}_{2}\right)$ and organic hydroperoxides ( $\left.\mathrm{ROOH}\right)$ ) which act as important oxidants of $\mathrm{SO}_{2}$ in the liquid phase (Watanabe and others, 2009).

Mount Tateyama (3015 ma.s.I.), a part of the mountain range in the Hokuriku District (Japan Sea side in central Japan), is near the Japan Sea coast in central Japan, where a large amount of air pollution may be transported from Asia as well as from industrial regions in Japan. Recently, a serious decline of the forest in the vicinity of Mount Tateyama has been observed (Kume and others, 2009). Observation of the atmospheric environment at Mount Tateyama has been typically performed in summer and autumn (Watanabe and others, 2006b, 2010a). Due to severe conditions, it is difficult to perform direct observation from late autumn to spring. The large amount of snow cover formed in spring at Mount Tateyama not only acts as a water resource in the Hokuriku District but also records the environmental signals at high altitude during the cold months (6 months, November-April). More than $5 \mathrm{~m}$ of snow cover is formed every April near the summit of Mount Tateyama. Snowmelt runoff is caused after May, and snow cover usually becomes extinct in July.

Snow-pit observation at a high elevation is useful to evaluate air quality in the free troposphere during cold months. In a previous study at Mount Tateyama in the 1990s (Osada and others, 2000, 2004), the chemical composition in snow was measured. Osada and others (2004) elucidated the formation processes of mineral dust layers in snow at Mount Tateyama. A snow-pit study was also conducted in the northern Japan Alps (Shah and others, 2008). However, there is a shortage of chemistry data in snow pits at highelevation sites $(>2000 \mathrm{~m}$ ) in Japan where trans-boundary air pollution and Kosa particles are actively transported. Moreover, measurements of peroxides in snow in an alpine region have scarcely been performed, especially in Japan, while peroxides in polar snow have been investigated (Bales and others, 1995; Neftel and others, 1995; Kamiyama and others, 1996; McConnell and others, 1997, 1998; Jacobi and others, 2002; Hutterli and others, 2003). Measurements of peroxides in an ice core may give information about the past atmospheric oxidation conditions (Sigg and Neftel, 1988, 1991; Watanabe and others, 1998; Gillett and others, 2000; 


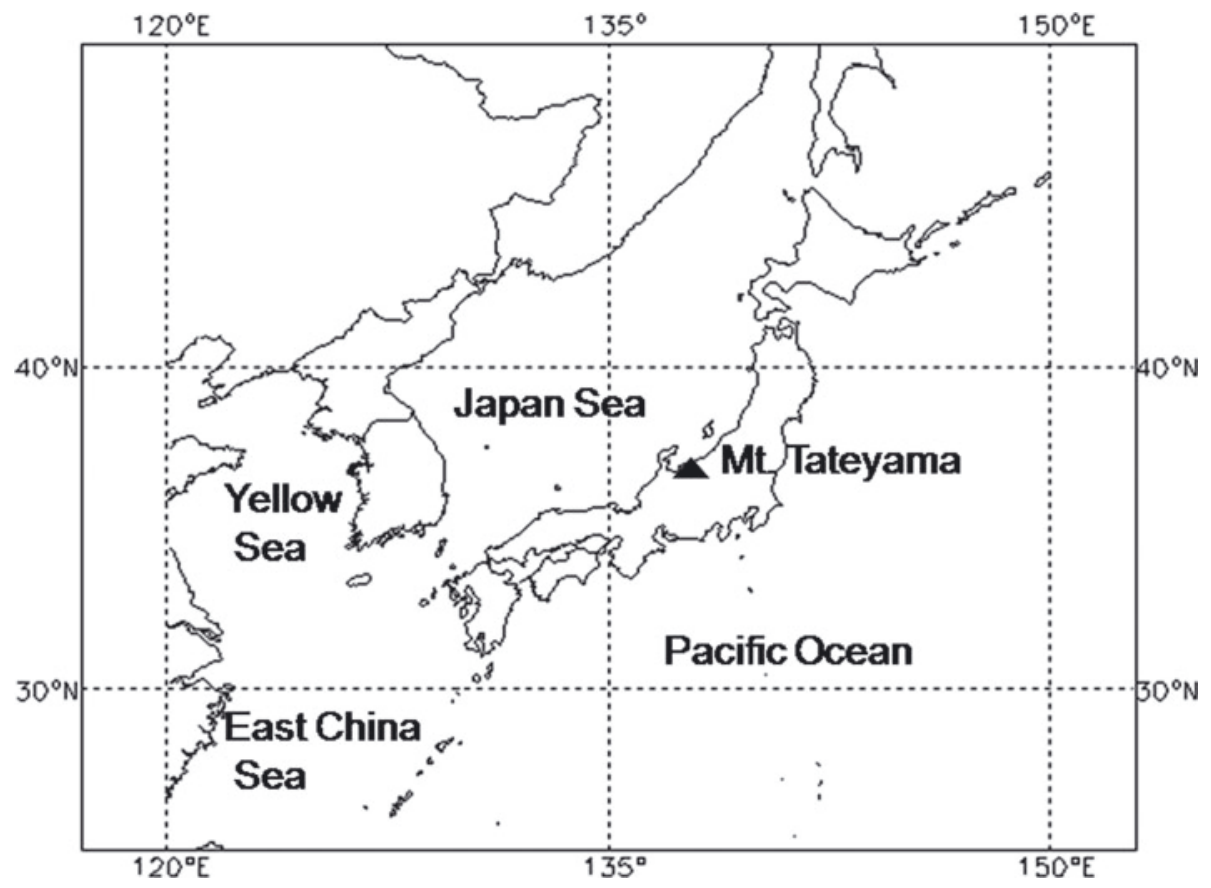

Fig. 1. Map of Japan showing the location of Mount Tateyama.

Frey and others, 2007). The peroxide concentrations in snow are highly affected by post-depositional modification (Neftel and others, 1995; McConnell and others, 1997, 1998; Hutterli and others, 2003). At Mount Tateyama, environmental factors (e.g. temperature and impurities concentrations) are significantly different from those in polar regions; however, snow-pit observations may also be useful for the interpretation of ice-core analysis, especially for unstable species such as peroxides.

The aim of this study is to understand the behavior of snow chemistry at Mount Tateyama, especially the concentrations of acidic species, chemical stratigraphy and the relationship between the concentrations of peroxides and snow type or quality and ionic species. In this paper, the characteristics of the chemical composition, including peroxides, in the snow pits at Murododaira, near the summit of Mount Tateyama, are examined.

\section{METHODS}

Figure 1 is a map of Japan showing the location of Mount Tateyama. The snow-pit observation was performed at Murododaira $\left(36.6^{\circ} \mathrm{N}, 137.6^{\circ} \mathrm{E} ; 2450 \mathrm{ma.s.l}\right.$.), near the summit of Mount Tateyama (Fig. 1), Toyama Prefecture, Japan, on 22-24 April 2005, 20-22 April 2006, 19-21 April 2007 and 18-20 April 2008. The snow cover at the sampling site from 2005 to 2008 was $6.4 \mathrm{~m}$ (3.0 mw.e.), $8.5 \mathrm{~m}$ (4.0 m w.e.), $5.6 \mathrm{~m}$ ( $2.5 \mathrm{~m}$ w.e.) and $6.6 \mathrm{~m}$ (3.1 m w.e.) deep, respectively. Snow temperature in the pits was $<0^{\circ} \mathrm{C}$; therefore, leaching of chemical constituents might have been suppressed, and ionic constituents might have been well preserved during the 6 months (November-April).

Snow samples were collected from the pit wall after observation of stratigraphy and measurement of density, and the sampling interval for chemical analysis was usually $10 \mathrm{~cm}$. Unfortunately, sampling below depths of 4 and $5 \mathrm{~m}$ could not be done in 2005 and 2006, respectively. Snow samples could be taken from the top to the bottom in 2007 and 2008. Snow samples that had not melted were transported to Toyama Prefectural University and preserved in a freezer $\left(-10^{\circ} \mathrm{C}\right)$. Measurements of peroxides were performed within 1 week. The snow samples were melted just before the analysis of peroxides. Unfortunately, the peroxide concentrations could not be measured below $4 \mathrm{~m}$ depth in the 2006 pit. The $\mathrm{pH}$ of the melted solution was measured by an electrode using a $\mathrm{pH}$ meter. The dissolved ionic species were analyzed using an ion chromatograph (Yokogawa, IC7000).

Peroxide concentrations were measured by the fluorometric method (Lazrus and others, 1985) using p-hydroxyphenyl acetic acid and peroxidase reagents as described in detail by Watanabe and others (2005c). The fluorescence reagents, $1 \mathrm{~mL}$-hydroxyphenyl acetic acid $\left(1.5 \times 10^{-2} \mathrm{M}\right)$ in a phosphate buffer (adjusted to $\mathrm{pH}$ 7) and $1 \mathrm{~mL}$ peroxidase ( 50 unit $\mathrm{mL}^{-1}$ ) in a phosphate buffer (adjusted to $\mathrm{pH}$ 7), were added to the $1 \mathrm{~mL}$ liquid sample. Several minutes later, $1 \mathrm{~mL} \mathrm{NaOH}(1 \mathrm{~N})$ was added to stabilize the generated fluorescence. The amount of fluorescence in the solution was determined using a fluorescence spectrophotometer (Hitachi Corporation, Model F-2500). This method determines the concentration of total peroxides $\left(\mathrm{H}_{2} \mathrm{O}_{2}+\mathrm{ROOH}\right)$. The detection limit was $0.1 \mu \mathrm{mol} \mathrm{kg}^{-1}$. To calibrate, a standard $\mathrm{H}_{2} \mathrm{O}_{2}$ solution was made from a stock solution titrated with a standard $\mathrm{KMnO}_{4}$ solution. We also determined individual peroxides using HPLC separation (Kok and others, 1995). The concentrations of organic hydroperoxides (e.g. methylhydroperoxide (MHP)) were not detected. Therefore, peroxides in the snow pits can be regarded as $\mathrm{H}_{2} \mathrm{O}_{2}$.

\section{RESULTS AND DISCUSSION}

\subsection{Major ions}

A summary of the chemistry in the snow pits at Murododaira (2450 ma.s.l.) in April from 2005 to 2008 is presented in Table 1 . The levels of non-sea-salt sulfate $\left(\mathrm{nssSO}_{4}{ }^{2-}\right)$ and 


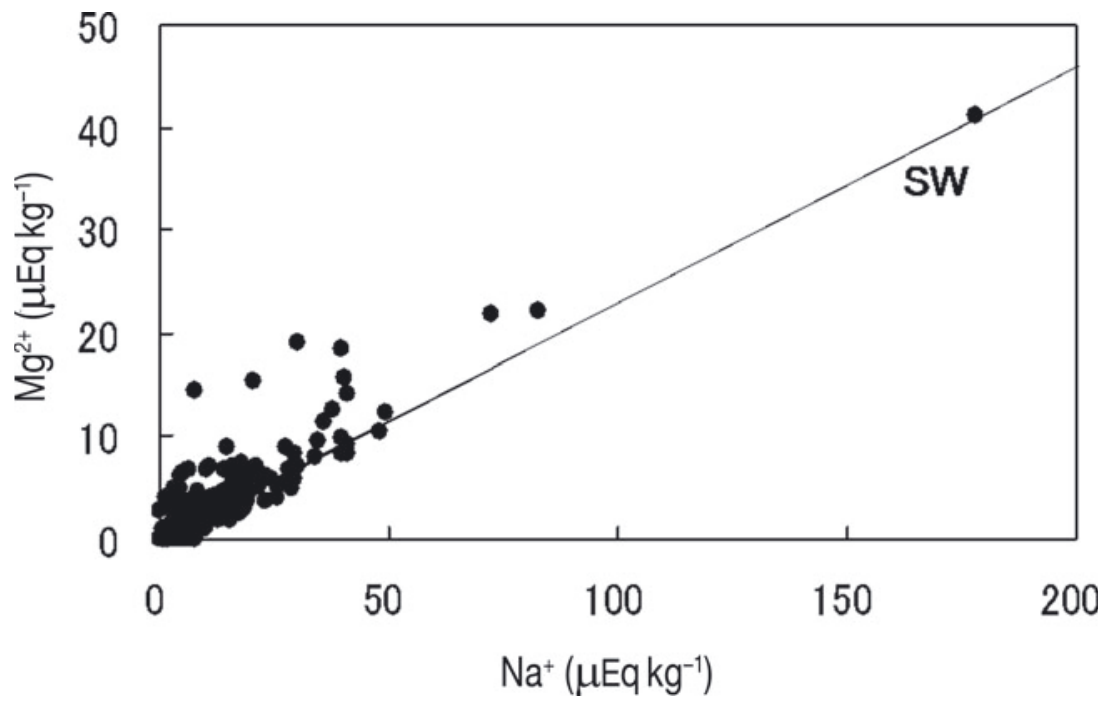

Fig. 2. Relationship between $\mathrm{Na}^{+}$and $\mathrm{Mg}^{2+}$ concentrations in the snow pits at Murododaira from 2005 to 2008. SW indicates the ratio in the case of sea water.

non-sea-salt calcium (nssCa $\left.{ }^{2+}\right)$ were calculated using

$$
\begin{aligned}
& \mathrm{nssSO}_{4}{ }^{2-}=\mathrm{SO}_{4}{ }^{2-}-\left(\mathrm{SO}_{4}{ }^{2-} / \mathrm{Na}^{+}\right)_{\text {sea water }} \mathrm{Na}^{+}, \\
& \mathrm{nssCa}^{2+}=\mathrm{Ca}^{2+}-\left(\mathrm{Ca}^{2+} / \mathrm{Na}^{+}\right)_{\text {sea water }} \mathrm{Na}^{+},
\end{aligned}
$$

where $\left(\mathrm{SO}_{4}{ }^{2-} / \mathrm{Na}^{+}\right)_{\text {sea }}$ water and $\left(\mathrm{Ca}^{2+} / \mathrm{Na}^{+}\right)_{\text {sea }}$ water are the concentration ratios of $\mathrm{SO}_{4}{ }^{2-}$ to $\mathrm{Na}^{+}$and $\mathrm{Ca}^{2+}$ to $\mathrm{Na}^{+}$in sea water, which are 0.12 and 0.044 (equivalent ratio), respectively (Keene and others, 1986). The ionic species can be classified into three types by their origin: anthropogenic pollution $\left(\mathrm{NO}_{3}{ }^{-}, \mathrm{nssSO}_{4}{ }^{2-}\right.$ and $\left.\mathrm{NH}_{4}{ }^{+}\right)$, sea-salt particles $\left(\mathrm{Na}^{+}, \mathrm{Cl}^{-}\right.$and $\mathrm{Mg}^{2+}$ ) and Kosa particles $\left(\mathrm{nssCa}^{2+}\right)$ (Osada and others, 2000). The concentrations of major ions were much higher than those in polar regions (Motoyama and others, 2001; Frey and others, 2007; Virkkunen and others, 2007). The range in $\mathrm{pH}$ was 4.0-6.0. Acidic snow was deposited at Murododaira. Sulfuric and nitric acids contribute to the acidification of precipitation.

As mentioned above, the ionic constituents seemed to be well preserved in the snow pits during the 6 months. The mean concentrations of $\mathrm{nssSO}_{4}{ }^{2-}$ and $\mathrm{NO}_{3}{ }^{-}$from 2005 to 2008 are $21-27$ and $7-12 \mu \mathrm{Eq} \mathrm{kg}^{-1}$, respectively (Table 1); they are higher than those in no-melt snowpack at Murododaira in the 1990s reported by Osada and others (2000). On the other hand, no significant difference is seen between the concentrations of the other ions in the 2000s and those in the 1990s. Anthropogenic emission (e.g. $\mathrm{SO}_{2}$ ) in China has increased since 2000 (Ohara and others, 2007). According to Osada and others (2009), significant increasing trends of submicrometer aerosols, which might have been mainly contributed by Chinese-derived anthropogenic emission, at Mount Tateyama were found during winter to spring in the 2000s. The $\mathrm{nsSO}_{4}{ }^{2-}$ and $\mathrm{NO}_{3}{ }^{-}$deposition also seemed to increase at Murododaira during the cold months. We estimated the sub-annual (6 months, November-April) deposition of $\mathrm{nsSSO}_{4}{ }^{2-}$ and $\mathrm{NO}_{3}{ }^{-}$at Murododaira to be 66-

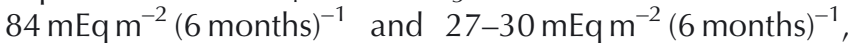
respectively. The calculated deposition fluxes are significantly higher than those at low altitude on the Japan Sea side shown in Noguchi and others (2007).

In this study, the snow-pit observation was performed before the melt season (usually after May at Murododaira). Snow temperature in the pits was $<0^{\circ} \mathrm{C}$. The pit walls were mainly composed of compacted snow (fine grain, non-melt rounded grains) or solid-type depth hoar (faceted crystals); however, granular snow (coarse grain, melt forms) layers were sporadically seen in the snow pits. The relationship between $\mathrm{Na}^{+}$and $\mathrm{Mg}^{2+}$ concentrations in the snow pits at Murododaira in April from 2005 to 2008 is shown in Figure 2. Most of the samples are similar to the $\mathrm{Mg}^{2+} / \mathrm{Na}^{+}$

Table 1. Summary of the chemistry in the snow pits at Murododaira (2450 m a.s.l.), measured each April from 2005 to 2008 . The units of the concentrations of peroxides and ions are $\mu \mathrm{mol} \mathrm{kg} \mathrm{g}^{-1}$ and $\mu \mathrm{Eq} \mathrm{kg}^{-1}$, respectively. $N$ and BDL denote the number of samples and a value below

\begin{tabular}{|c|c|c|c|c|c|c|c|c|c|c|c|c|c|}
\hline Date & $N$ & $\mathrm{pH}$ & Peroxides & $\mathrm{Cl}^{-}$ & $\mathrm{NO}_{3}{ }^{-}$ & $\mathrm{SO}_{4}{ }^{2-}$ & $\mathrm{nssSO}_{4}{ }^{2-}$ & $\mathrm{Na}^{+}$ & $\mathrm{NH}_{4}{ }^{+}$ & $\mathrm{K}^{+}$ & $\mathrm{Mg}^{2+}$ & $\mathrm{Ca}^{2+}$ & $\mathrm{nssCa}^{2+}$ \\
\hline $\begin{array}{l}\text { 22-24 Apr } 2005 \\
\text { (Mean) }\end{array}$ & 42 & $\begin{array}{c}4.2-6.0 \\
(4.9)\end{array}$ & $\begin{array}{c}\text { BDL-2.7 } \\
(0.2)\end{array}$ & $\begin{array}{l}1-67 \\
(17)\end{array}$ & $\begin{array}{c}0-49 \\
(9)\end{array}$ & $\begin{array}{c}4-94 \\
(24)\end{array}$ & $\begin{array}{c}3-90 \\
(22)\end{array}$ & $\begin{array}{l}1-83 \\
(16)\end{array}$ & $\begin{array}{c}0-43 \\
(8)\end{array}$ & $\begin{array}{c}0-23 \\
(3)\end{array}$ & $\begin{array}{c}0-22 \\
(4)\end{array}$ & $\begin{array}{c}1-102 \\
(12)\end{array}$ & $\begin{array}{c}0-100 \\
(10)\end{array}$ \\
\hline $\begin{array}{l}\text { 20-22 Apr } 2006 \\
\text { (Mean) }\end{array}$ & 50 & $\begin{array}{c}4.0-5.9 \\
(4.8)\end{array}$ & $\begin{array}{l}\text { BDL-3.4 } \\
(0.4)\end{array}$ & $\begin{array}{c}0-36 \\
(12)\end{array}$ & $\begin{array}{c}1-34 \\
(7)\end{array}$ & $\begin{array}{l}1-90 \\
(22)\end{array}$ & $\begin{array}{l}1-89 \\
(21)\end{array}$ & $\begin{array}{c}0-34 \\
(6)\end{array}$ & $\begin{array}{c}0-30 \\
(7)\end{array}$ & $\begin{array}{c}0-11 \\
(1)\end{array}$ & $\begin{array}{c}0-7 \\
(3)\end{array}$ & $\begin{array}{c}0-37 \\
(8)\end{array}$ & $\begin{array}{c}0-36 \\
(8)\end{array}$ \\
\hline $\begin{array}{l}\text { 19-21 Apr } 2007 \\
\text { (Mean) }\end{array}$ & 56 & $\begin{array}{c}4.0-5.7 \\
(4.7)\end{array}$ & $\begin{array}{c}\text { BDL-2.4 } \\
(0.2)\end{array}$ & $\begin{array}{c}1-220 \\
(23)\end{array}$ & $\begin{array}{l}5-55 \\
(12)\end{array}$ & $\begin{array}{c}6-105 \\
(30)\end{array}$ & $\begin{array}{c}6-102 \\
(27)\end{array}$ & $\begin{array}{c}1-200 \\
(20)\end{array}$ & $\begin{array}{c}2-94 \\
(12)\end{array}$ & $\begin{array}{c}0-8 \\
(2)\end{array}$ & $\begin{array}{c}0-44 \\
(5)\end{array}$ & $\begin{array}{c}0-71 \\
(6)\end{array}$ & $\begin{array}{l}0-70 \\
(5)\end{array}$ \\
\hline $\begin{array}{l}\text { 18-20 Apr } 2008 \\
\text { (Mean) }\end{array}$ & 66 & $\begin{array}{c}4.2-5.8 \\
\quad(4.8)\end{array}$ & $\begin{array}{c}\text { BDL-1.9 } \\
(0.3)\end{array}$ & $\begin{array}{l}1-80 \\
(17)\end{array}$ & $\begin{array}{l}1-61 \\
(10)\end{array}$ & $\begin{array}{c}2-127 \\
(28)\end{array}$ & $\begin{array}{c}1-118 \\
(26)\end{array}$ & $\begin{array}{l}1-72 \\
(14)\end{array}$ & $\begin{array}{c}0-67 \\
(10)\end{array}$ & $\begin{array}{c}0-6 \\
(1)\end{array}$ & $\begin{array}{c}0-21 \\
(4)\end{array}$ & $\begin{array}{c}0-69 \\
(7)\end{array}$ & $\begin{array}{c}0-68 \\
(6)\end{array}$ \\
\hline
\end{tabular}
the detection limit of peroxides, $<0.1 \mu \mathrm{mol} \mathrm{kg}^{-1}$, respectively 

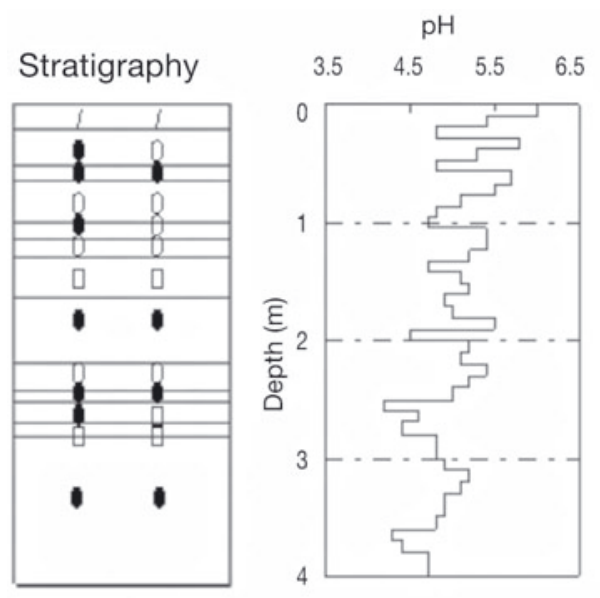

$\mathrm{Na}^{+}(\mu \mathrm{eqkg})$
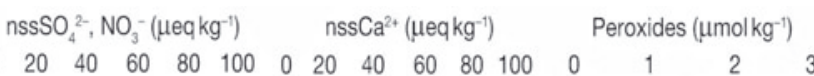

\section{Stratigraphy}
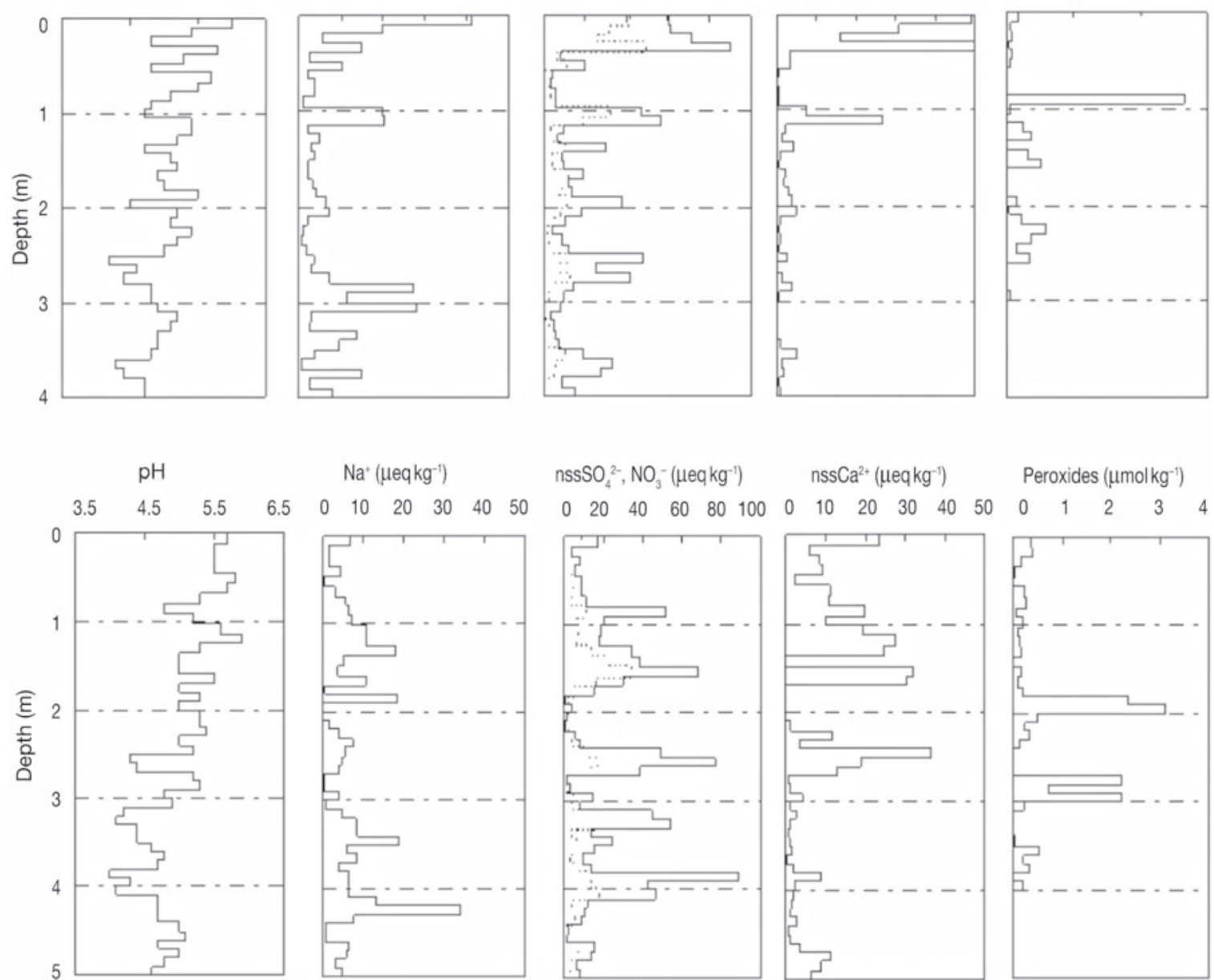

$\mathrm{Na}^{+}\left(\mu \mathrm{eq} \mathrm{kg}{ }^{-1}\right)$

$\left.\mathrm{nsSSO}_{4}^{2-}, \mathrm{NO}_{3}^{-}(\mu \mathrm{eqkg})^{-1}\right)$

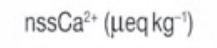

Peroxides $\left(\mu \mathrm{mol} \mathrm{kg}{ }^{-1}\right)$
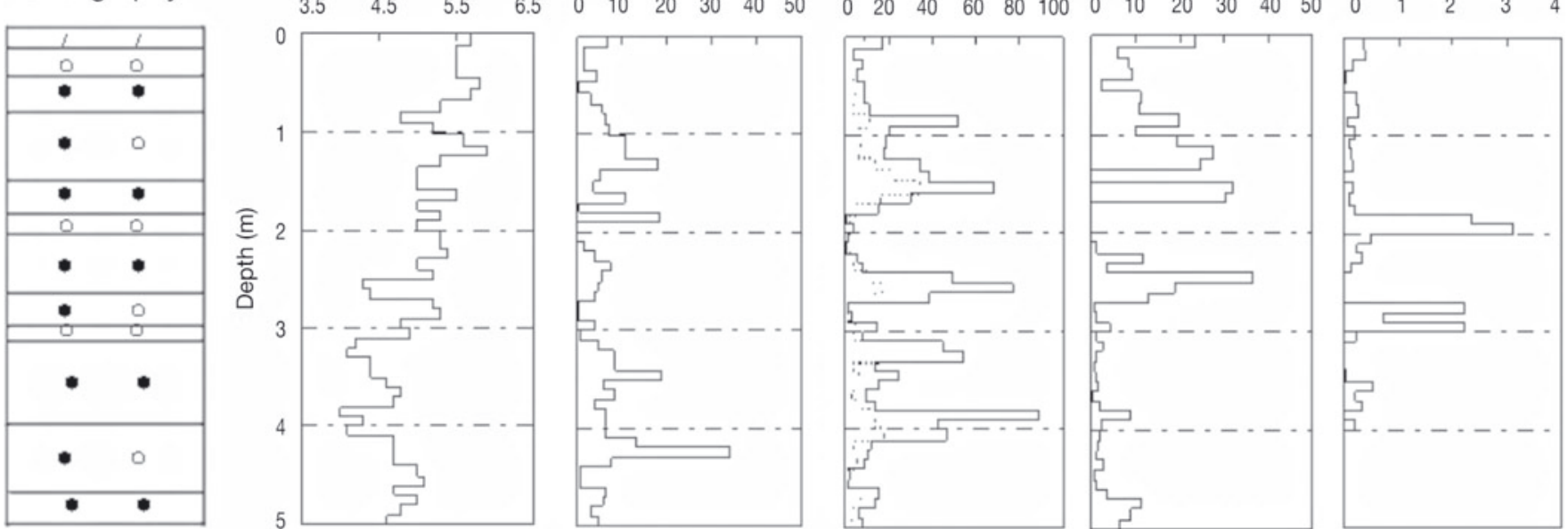

Fig. 3. Stratigraphy (/: lightly compacted snow (decomposing and fragmented precipitation particles); filled circles: compacted snow (fine grain, rounded grains); open circles: granular snow (coarse grain, melt forms); squares: solid-type depth hoar (faceted crystals)) and vertical profiles of $\mathrm{pH}, \mathrm{Na}^{+}, \mathrm{nsSSO}_{4}{ }^{2-}, \mathrm{NO}_{3}{ }^{-}$(dotted line), $\mathrm{nssCa}^{2+}$ and peroxide concentrations in the snow pits at Murododaira in April 2005 (upper panel) and 2006 (lower panel). Peroxide concentrations could not be measured below $4 \mathrm{~m}$ depth in the 2006 pit.

ratio in sea water (or higher than the ratio in sea water; the higher $\mathrm{Mg}^{2+}$ is due to dust particles). A low ratio of $\mathrm{Mg}^{2+} /$ $\mathrm{Na}^{+}$(or a high ratio of $\log \left(\mathrm{Na}^{+} / \mathrm{Mg}^{2+}\right)$ ) is evidence of deep percolation or runoff of ions (lizuka and others, 2000, 2002; Virkkunen and others, 2007). High values of the melt indicator $\log \left(\mathrm{Na}^{+} / \mathrm{Mg}^{2+}\right)$ have been observed in Svalbard (Virkkunen and others, 2007). A significantly low $\mathrm{Mg}^{2+} / \mathrm{Na}^{+}$ ratio was also detected in the snowpack at Murododaira during melting (personal communication from $\mathrm{K}$. Watanabe, 2010); however, a low ratio of $\mathrm{Mg}^{2+} / \mathrm{Na}^{+}$was not seen in the pits from 2005 to 2008 (Fig. 2). Redistribution of ions by meltwater percolation is not significant in this study.

Figure 3 shows the stratigraphy and the vertical profiles of the $\mathrm{pH}, \mathrm{Na}^{+}, \mathrm{nssSO}_{4}{ }^{2-}, \mathrm{NO}_{3}{ }^{-}, \mathrm{nssCa}^{2+}$ and peroxide concentrations in the snow pits at Murododaira in April 2005 (from the top to $4 \mathrm{~m}$ depth) and 2006 (from the top to $5 \mathrm{~m}$ depth). The concentrations of $\mathrm{nssCa}^{2+}$ were high in the layers higher than $2-3 \mathrm{~m}$ depth (Fig. 3). The high concentrations of $\mathrm{nsSCa}^{2+}$ are due to Kosa particles, rich in $\mathrm{CaCO}_{3}$, which are actively transported over Japan in spring (Watanabe and others, 2005a, 2006c), and correspond to the dust layers. There is heavy snow cover near the sampling site in winter and spring; therefore, local soil dust is not blown up. Snow layers higher than $2-3 \mathrm{~m}$ depth may be deposited during the spring months. Layers lower than $2-3 \mathrm{~m}$ depth may be regarded as sediment in the winter, and the bottom of the snow pits seems to be deposited during late autumn. Kosa particles contribute to the neutralization of acidic species; therefore, the $\mathrm{pH}$ in the snow was also high in the parts higher than $3 \mathrm{~m}$. No vertical trend of $\mathrm{Na}^{+}, \mathrm{nssSO}_{4}{ }^{2-}$ and $\mathrm{NO}_{3}{ }^{-}$was seen. Sea-salt particles and air pollutants may be transported in both the winter and spring. High concentrations of $\mathrm{Na}^{+}$, which might have been due to the transport of abundant sea-salt particles, were detected at 1 and $3 \mathrm{~m}$ depth in the 2005 pit and $4.2 \mathrm{~m}$ depth in the 2006 pit (Fig. 3). During the strong monsoon wind, convective activity over the Japan Sea side is sometimes accelerated, and sea-salt particles are transported vertically. High concentrations of $\mathrm{nssSO}_{4}{ }^{2-}$ or $\mathrm{NO}_{3}{ }^{-}$are due to the transport of air pollution. The high-nss $\mathrm{SO}_{4}{ }^{2-}$ layers deposited in the winter (e.g. at $3.7 \mathrm{~m}$ depth in the 2005 pit and $\sim 4 \mathrm{~m}$ depth in the 2006 pit) correspond to the low-pH layers. Long- or middle-range transport of pollutants may accelerate the acidification of precipitation in winter.

Figure 4 shows the stratigraphy and the vertical profiles of $\mathrm{nssSO}_{4}{ }^{2-}, \mathrm{nssCa}^{2+}$ and peroxide concentrations in the snow pits from the top to the bottom at Murododaira in April 2007 and 2008. The $\mathrm{pH}, \mathrm{Na}^{+}$and $\mathrm{NO}_{3}{ }^{-}$were not shown in 


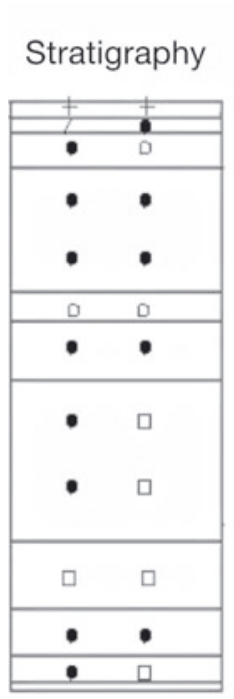

Stratigraphy

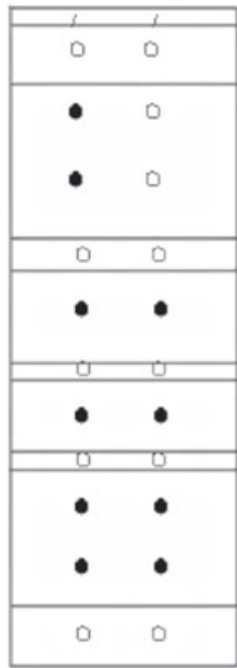

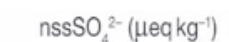
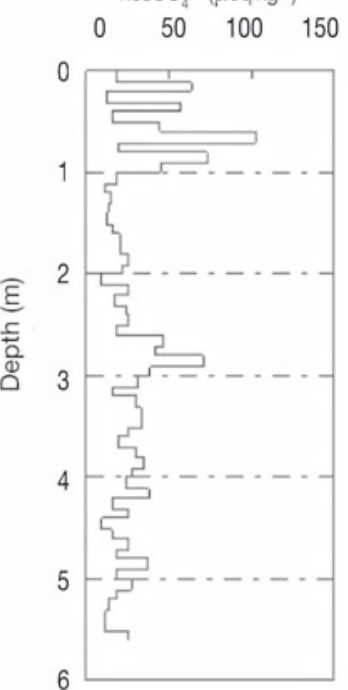

$\left.\mathrm{nsSSO}_{4}^{2-}(\mu \mathrm{eq} \mathrm{kg})^{-1}\right)$

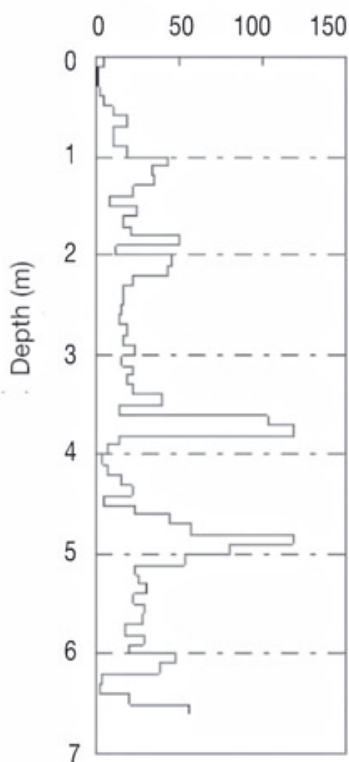

nssCa ${ }^{2+}\left(\mu \mathrm{eq} \mathrm{kg}{ }^{-1}\right)$
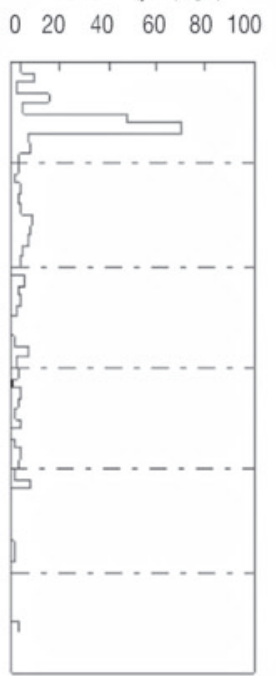

$n s \mathrm{Ca}^{2+}\left(\mu \mathrm{eq} \mathrm{kg}{ }^{-1}\right)$
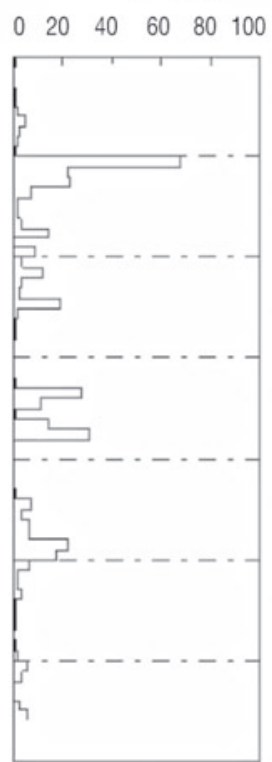

Peroxides $(\mu \mathrm{mol} \mathrm{kg-1})$
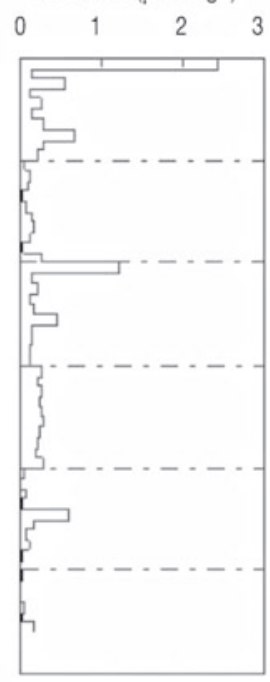

Peroxides $\left(\mu \mathrm{mol} \mathrm{kg}{ }^{-1}\right)$
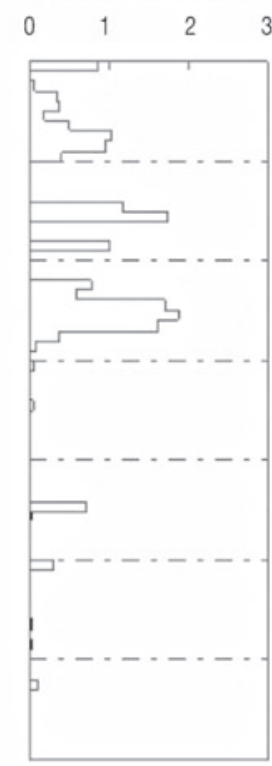

Fig. 4. Stratigraphy (+: new snow (precipitation particles); /: lightly compacted snow (decomposing and fragmented precipitation particles); filled circles: compacted snow (fine grain, rounded grains); open circles: granular snow (coarse grain, melt forms); squares: solid-type depth hoar (faceted crystals)) and vertical profiles of $\mathrm{nsSSO}_{4}{ }^{2-}, \mathrm{nssCa}^{2+}$ and peroxide concentrations in the snow pits from the top to the bottom at Murododaira in April 2007 (upper panel) and 2008 (lower panel).

Figure 4. High concentrations of $\mathrm{nssCa}^{2+}$ were detected above $1 \mathrm{~m}$ in the 2007 pit; however, the relatively high peaks of nssCa ${ }^{2+}$ were also observed below $3 \mathrm{~m}$ depth in the 2008 pit deposited in the winter. Judging from the results of the pit observation, transport of Kosa particles during winter might have been more active in 2008 than in the other years. No vertical trend of $\mathrm{nsSSO}_{4}{ }^{2-}$ was seen in the 2007 and 2008 pits.

The peaks of nssCa ${ }^{2+}$ in the snow pits usually correspond to the layers containing high concentrations of $\mathrm{nssSO}_{4}{ }^{2-}$ (Figs 3 and 4). The results show that not only Kosa particles but also air pollutants might have been transported longrange from the Asian continent. A typical example (21 April 2005) of 5 day backward trajectories by the Hybrid SingleParticle Lagrangian Integrated Trajectory 4 model (US National Oceanic and Atmospheric Administration (NOAA) Air Resources Laboratory (ARL), Silver Spring, MD, 1997, available at http://www.arl.noaa.gov/ready/hysplit4.html) is illustrated in Figure 5. The starting heights for the calculations were 2000, 2500 and $3000 \mathrm{~m}$. High concentrations of $\mathrm{nssSO}_{4}{ }^{2-}$ and $\mathrm{nssCa}^{2+}$ were recorded in the surface layer deposited on 21 April 2005 (snowfall was observed) before the snow-pit observation of 2005 (Fig. 3a). The air mass originating in the arid regions of the Asian continent was transported to Mount Tateyama through the polluted areas of the continent, especially from the coasts of the Yellow Sea, where $\mathrm{SO}_{2}$ emission is large (Ohara and others, 2007). To elucidate the transport processes of Kosa particles and air pollution requires more analysis; however, precise dating of the snow layers, which is needed for trajectory analysis, is unavailable. In this study, the typical case on 21 April 2005 (dating is reliable) is shown.

\subsection{Peroxides}

The concentrations of peroxides in the snow pits ranged from below the level of detection to $3.1 \mu \mathrm{mol} \mathrm{kg}{ }^{-1}$. There are 


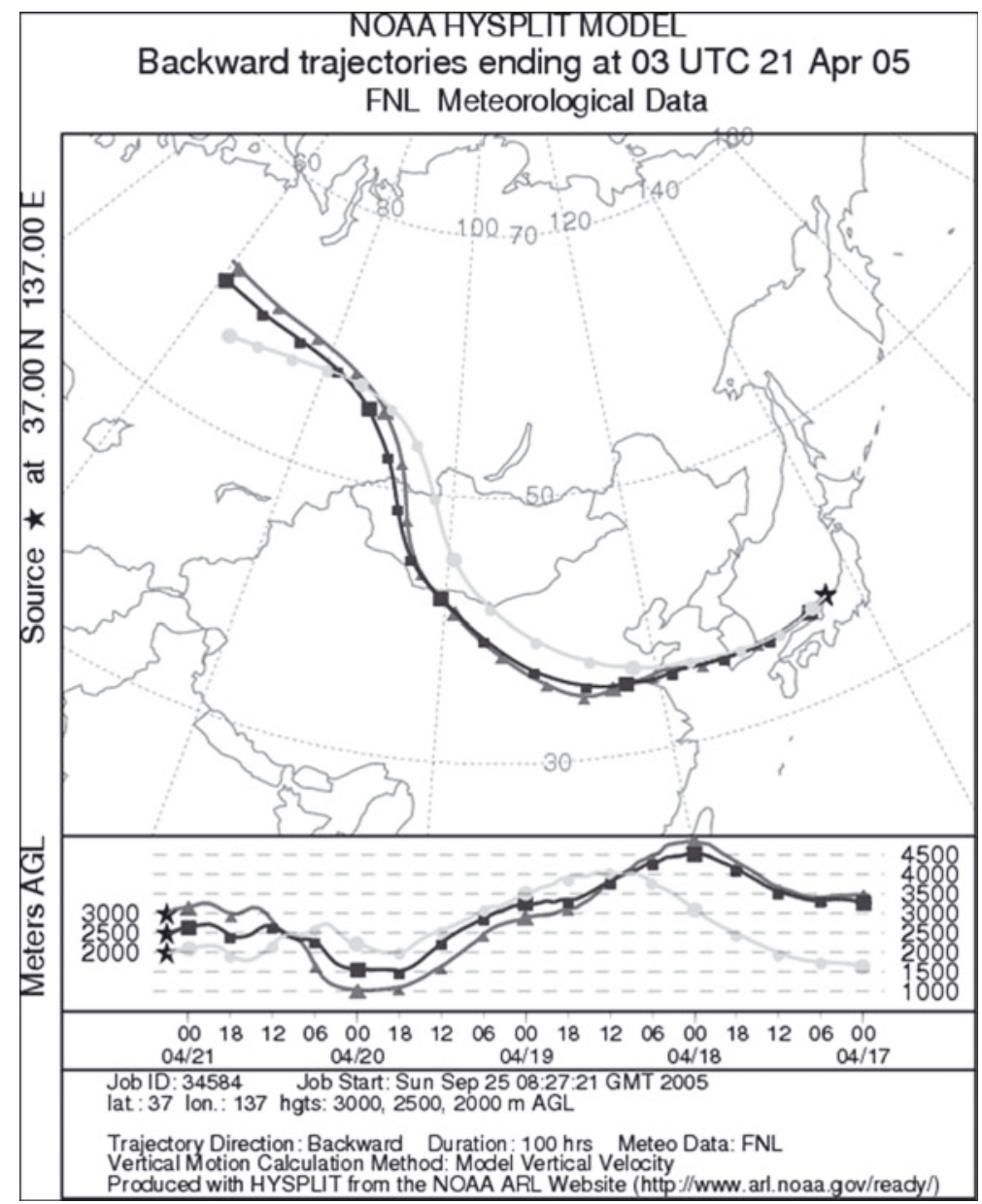

Fig. 5. Results of 5 day backward trajectory analysis; the starting time is $12 \mathrm{~h}$ Japan Standard Time (JST) (3 h UTC) on 21 April 2005. AGL: above ground level.

comparable peroxide data in the snow pits in polar regions. The peroxide concentrations at Murododaira were lower than those in snow samples from the pit wall at NorthGRIP, Greenland (Motoyama and others, 2001). Sigg and others (1992) reported that a high concentration of $\mathrm{H}_{2} \mathrm{O}_{2}$ in the air was observed during summer at Summit, Greenland, and the $\mathrm{H}_{2} \mathrm{O}_{2}$ concentration in fresh snow samples was $\sim 20 \mu \mathrm{mol}$ $\mathrm{kg}^{-1}$. High concentrations of $\mathrm{H}_{2} \mathrm{O}_{2}$ were detected in the snow layers deposited during summer and autumn in Greenland (Motoyama and others, 2001). The peroxide concentrations at Murododaira were similar to those in the snow pits in Svalbard (Motoyama and others, 2001). The $\mathrm{H}_{2} \mathrm{O}_{2}$ in Svalbard might have been flushed out by the percolation of snowmelt water after accumulation.

The peroxide concentrations in new snow (precipitation particles) were higher than those in compacted snow (fine grain, rounded grains) or lightly compacted snow (decomposing and fragmented precipitation particles). During the 2007 pit study, the highest concentration was detected in the surface new snow layer (Fig. 4a). New snow layers were not seen in the pits during the 2005, 2006 and 2008 observations (Figs 3 and 4); fortunately, snowfall samples (new snow samples) could be taken at Murododaira just after the pit observations in 2006 and 2008. Table 2 shows the range of the concentrations of peroxides, major ions and $\mathrm{pH}$ in the new snow (precipitation particles) samples at Murododaira in 2006 and 2008. The new snow samples contained high concentrations of peroxides. The concentrations of peroxides were 4.4-5.5 $\mu \mathrm{mol} \mathrm{kg}^{-1}$ in April 2006 and 2.0-7.1 $\mu \mathrm{mol} \mathrm{kg}^{-1}$ in April 2008 (Table 2).

According to Sigg and others (1992), the diffusional growth of snow is an important process of $\mathrm{H}_{2} \mathrm{O}_{2}$ scavenging. There is no fractionation between $\mathrm{H}_{2} \mathrm{O}_{2}$ and $\mathrm{H}_{2} \mathrm{O}$ during diffusional growth (co-condensation). Assuming that COcondensation could be applied, we roughly estimated the concentration of $\mathrm{H}_{2} \mathrm{O}_{2}$ in the atmosphere before snowfall events by the mean peroxide concentration in the new snow samples $\left(C=4.5 \mu \mathrm{mol} \mathrm{kg}{ }^{-1}\right)$, air pressure $\left(P=7.45 \times 10^{4} \mathrm{~Pa}\right)$, ambient air temperature $(T=268 \mathrm{~K})$, and water vapor content $\left(W=3.0 \mathrm{~g} \mathrm{~m}^{-3}\right)$ at Murododaira as follows:

$$
\left(\mathrm{H}_{2} \mathrm{O}_{2}\right)_{\text {air }}=C W R T / P \text {, }
$$

where $\left(\mathrm{H}_{2} \mathrm{O}_{2}\right)$ air is the $\mathrm{H}_{2} \mathrm{O}_{2}$ concentration in the ambient air (ppbv) and $R$ is the gas constant $\left(8.31 \mathrm{~J} \mathrm{~mol}^{-1} \mathrm{~K}^{-1}\right)$. The calculated $\mathrm{H}_{2} \mathrm{O}_{2}$ concentration is $\sim 0.4$ ppbv and corresponded well to the $\mathrm{H}_{2} \mathrm{O}_{2}$ concentration over the Hokuriku District during the cold months (Watanabe and others, 2010b). The concentration is also comparable with the $\mathrm{H}_{2} \mathrm{O}_{2}$ mixing ratio at Summit, Greenland, in spring (Frey and others, 2009).

The concentrations of peroxides in the upper compacted and lightly compacted snow layers $\left(<1.0 \mu \mathrm{mol} \mathrm{kg}{ }^{-1}\right)$ were significantly lower than those in new snow samples (Figs 3 and 4). Moreover, the peroxide concentrations were very low in the compacted snow below $4 \mathrm{~m}$ depth, deposited mainly in winter; for example, the mean ratio of the 
Table 2. Summary of the chemistry in the new snow (precipitation particles) at Murododaira (2450 m a.s.l.) in April 2006 and 2008 . The units of the concentrations of peroxides and ions are $\mu \mathrm{mol} \mathrm{kg}{ }^{-1}$ and $\mu \mathrm{Eq} \mathrm{kg}^{-1}$, respectively. $N$ denotes the number of samples

\begin{tabular}{lcccccccccccccc}
\hline Date & $\mathrm{N}$ & $\mathrm{pH}$ & Peroxides & $\mathrm{Cl}^{-}$ & $\mathrm{NO}_{3}^{-}$ & $\mathrm{SO}_{4}^{2-}$ & $\mathrm{nssSO}_{4}{ }^{2-}$ & $\mathrm{Na}^{+}$ & $\mathrm{NH}_{4}^{+}$ & $\mathrm{K}^{+}$ & $\mathrm{Mg}^{2+}$ & $\mathrm{Ca}^{2+}$ & $\mathrm{nssCa}^{2+}$ \\
\hline 22 Apr 2006 & 3 & $4.4-5.0$ & $4.4-5.5$ & $8-19$ & $2-4$ & $5-13$ & $5-12$ & $3-8$ & $0-1$ & $0-1$ & $0-2$ & $3-4$ & $3-4$ \\
20 Apr 2008 & 5 & $5.0-5.4$ & $2.0-7.1$ & $1-8$ & $1-2$ & $2-7$ & $2-7$ & $0-1$ & $0-2$ & 0 & $0-1$ & $0-1$ & $0-1$ \\
\hline
\end{tabular}

peroxide concentration above and below $4 \mathrm{~m}$ depth to that in the new snow layer in the 2007 pit was $\sim 0.1$ and $\sim 0.04$, respectively. The results indicate that peroxides are decomposed and degassed in the process of metamorphism of new snow to compacted snow and reconstruction of atmospheric peroxide concentrations is difficult. Air-to-snow transfer processes of $\mathrm{H}_{2} \mathrm{O}_{2}$ in polar snow have been discussed (McConnell and others, 1997, 1998; Hutterli and others, 2003; Frey and others, 2007). $\mathrm{H}_{2} \mathrm{O}_{2}$ uptake in near-surface snow and firn has been observed, particularly at low temperature (Frey and others, 2006). $\mathrm{H}_{2} \mathrm{O}_{2}$ adsorption may be suppressed $\left(\mathrm{H}_{2} \mathrm{O}_{2}\right.$ desorption may be predominant) at Murododaira because of the relatively high temperature. Moreover, photolysis of peroxides in surface snow may be caused by intensive ultraviolet radiation, whereas the photolysis loss of $\mathrm{H}_{2} \mathrm{O}_{2}$ seems to be small (Grannas and others, 2007). According to France and others (2007), $\mathrm{H}_{2} \mathrm{O}_{2}$ photolysis in snowpack is an important source of hydroxyl radicals in the atmosphere.

The peroxide concentrations in the snow pits were much lower than those in rainwater during warm months (Watanabe and others, 2001b, 2005b, 2006a). It is natural for the photochemical production of peroxides to accelerate in warm months (Sakugawa and Kaplan, 1989; Watanabe and Tanaka, 1995). Peroxide concentrations are higher in rainwater than in snowfall in cold months (Watanabe and others, 2009). We simultaneously collected rainwater at Toyama Prefectural University (at low altitude in Toyama Prefecture) and snowfall (new snow) at Murododaira on 20 April 2003. The concentrations of peroxides were 1.0$2.0 \mu \mathrm{mol} \mathrm{kg}{ }^{-1}$ in the snow but $22 \mu \mathrm{mol} \mathrm{kg}{ }^{-1}$ in the rainwater (Watanabe and others, 2005c). The scavenging processes of $\mathrm{H}_{2} \mathrm{O}_{2}$, the main component of peroxides, from the atmosphere are different in rainwater and snowfall. While the diffusional growth of snow is an important process of $\mathrm{H}_{2} \mathrm{O}_{2}$ scavenging (c-condensation), $\mathrm{H}_{2} \mathrm{O}_{2}$ may be preferentially absorbed by rain droplets because of the high solubility of $\mathrm{H}_{2} \mathrm{O}_{2}$, for which Henry's law constant is high. Henry's law constant is given by Lind and Kok (1994) as follows:

$$
H(T)=\exp (A / T-B),
$$

where $H(T)$ is Henry's law constant $\left(\mathrm{Matm}^{-1}\right), T$ is the ambient temperature $(K), A=6338$ and $B=9.74$. The concentration of $\mathrm{H}_{2} \mathrm{O}_{2}$ in the gas phase during the rain at low altitude on 20 April 2003 was roughly calculated using Henry's law at $\sim 0.1$ ppbv. To estimate the $\mathrm{H}_{2} \mathrm{O}_{2}$ concentration in the atmosphere before the rain event, rainfall intensity data which could not be measured are required.

High concentrations of peroxides in the snow pits were also detected in the granular snow (coarse grain, melt forms) layers (e.g. at $0.9 \mathrm{~m}$ depth in the 2005 pit, 2 and $3 \mathrm{~m}$ depth in the 2006 pit, $2 \mathrm{~m}$ depth in the 2007 pit, and $2.5 \mathrm{~m}$ depth in the 2008 pit (Figs 3 and 4)). Granular snow (coarse grain, melt forms) is formed by percolation of rainwater or snowmelt water, which dissolves peroxides. Surface snowmelt water as well as rainwater seems to contain high concentrations of peroxides. As a result, relatively high concentrations of peroxides would be preserved in granular snow layers. The concentrations of peroxides were usually low below $4 \mathrm{~m}$ depth in snow pits. However, the peroxide peak was detected at $4.4 \mathrm{~m}$ depth in the 2008 pit, which corresponds to the granular snow layer (Fig. 4b). Recently, rain events were observed at Murododaira even in early spring and winter. Unfortunately, we cannot perform quantitative analysis because rainfall intensity data are not available at Murododaira. It is possible that warmer temperatures, which cause more rainfall events during cold months, may increase the peroxide concentrations recorded in snow cover in an alpine region, while the $\mathrm{H}_{2} \mathrm{O}_{2}$ adsorption by the air-to-snow transfer processes may be suppressed due to an increase in temperature.

A negative correlation was seen between the peroxides and the $\mathrm{nssCa}^{2+}$ (Figs 3 and 4). High concentrations of peroxides were detected in the layers in which nssCa ${ }^{2+}$ concentrations were low. Peroxides were hardly detected, particularly in the dust layers, where high concentrations of $\mathrm{nssCa}^{2+}$ were seen. This anticorrelation has been reported in ice cores. According to Fuhrer and others (1993), $\mathrm{H}_{2} \mathrm{O}_{2}$ was preserved in sections of ice from Greenland having low $\mathrm{Ca}^{2+}$. The high concentrations of $\mathrm{nssCa}^{2+}$ are due to the deposition of soil particles (Kosa particles), which contain abundant metal components. The metal components that act as catalysts might have decomposed the peroxides in snow. High peroxide concentrations may be preserved in granular snow layers having low concentrations of $\mathrm{nssCa}^{2+}$. The peroxide concentrations also anticorrelated with the nssSO $_{4}{ }^{2-}$ concentrations (Figs 3 and 4). It is possible that peroxides were also consumed by the liquid-phase oxidation of $\mathrm{SO}_{2}$. Detailed observation of stratigraphy and measurements of ionic species or trace metals may be important to interpret the past behavior of peroxides by icecore analysis.

\section{SUMMARY}

Snow cover at high elevations in Japan recorded atmospheric environmental signals during the winter and spring. Mount Tateyama is located near the coast of the Japan Sea, where air pollution and Asian dust (Kosa) particles are actively transported from the Asian continent. Snow-pit observation and sampling of snow in the pits at Murododaira ( 2450 ma.s.I.) near the summit of Mount Tateyama were performed each April from 2005 to 2008. Chemical analysis, such as $\mathrm{pH}$, major-ions and peroxide measurements of the snow samples, was conducted. The mean concentrations of nssSO ${ }_{4}{ }^{2-}$ and $\mathrm{NO}_{3}{ }^{-}$in the snow pits are higher than those in snowpack at Murododaira in the 1990s reported by Osada and others (2000). 
High concentrations of non-sea-salt sulfate $\left(\mathrm{nsSSO}_{4}{ }^{2-}\right)$, which might have been due to trans-boundary air pollution, were measured in both the winter snow layers and the spring layers. The $\mathrm{pH}$ of snow samples was usually higher in the layers deposited in the spring than in the winter layers. High concentrations of $\mathrm{nssCa}^{2+}$ corresponding to dust layers that might have been derived from Kosa particles were detected mainly in the spring layers. Kosa particles, rich in $\mathrm{CaCO}_{3}$, contributed to the neutralization of acid. The Kosa layers usually contained high concentrations of sulfate. The results indicate that Kosa particles might have been transported with air pollution from the continent.

The concentrations of peroxide were high in the new snow (precipitation particles) and granular snow (coarse grain, melt forms) layers in the snow pits. The peroxide concentrations in the snow layers were negatively correlated with the nssCa ${ }^{2+}$ concentrations. Peroxides were hardly detected, especially in the dust layers. Soil particles seemed to decompose the peroxides in snow. High peroxide concentrations may be preserved in granular snow layers having low concentrations of nssCa ${ }^{2+}$. Reconstruction of atmospheric peroxides in an alpine region during cold months from a snow-pit study is difficult. Detailed observation of stratigraphy and measurements of ionic species or trace metals may be important to interpret the past behavior of peroxides by ice-core analysis. More quantitative analysis is required.

\section{ACKNOWLEDGEMENTS}

We thank K. Satow, N. Wada, A. Kume, K. Aoki, W. Shimada, H. Honoki, I. Suzuki, H. lida, N. Ikeda, A. Tomatsu, K. Noritake, K. Yamada, N. Miyashita, M. Ohata, A. Takahashi, H. Kawamura, T. Murakami and F. Endo, and members of Toyama University, Toyama Prefectural University, Kanazawa University, Nagoya University, Tateyama Caldera Sabo Museum, Toyama Science Museum, Murodo-sanso, Tateyama Kurobe Kanko, Inc. and Toyama Prefecture Road Public Corporation, for their support and coordination of the snow-pit study at Mount Tateyama. This work was supported in part by Grant-in-Aid for Scientific Research from the Ministry of Education, Culture, Sports, Science and Technology (Nos. 16710011, 18310022, 20310113 and 22310022).

\section{REFERENCES}

Akimoto, H., H. Nakane and S. Matsumoto. 1994. The chemistry of oxidant generation: tropospheric ozone increase in Japan. In Calvert, J.G., ed. The chemistry of the atmosphere: its impact on global change. Oxford, Wiley-Blackwell, 261-273.

Bales, R.C., M.V. Losleben, J.R. McConnell, K. Fuhrer and A. Neftel. 1995. $\mathrm{H}_{2} \mathrm{O}_{2}$ in snow, air and open pore space in firn at Summit, Greenland. Geophys. Res. Lett., 22(10), 1261-1264.

France, J.L., M.D. King and J. Lee-Taylor. 2007. Hydroxyl $(\mathrm{OH})$ radical production rates in snowpacks from photolysis of hydrogen peroxide $\left(\mathrm{H}_{2} \mathrm{O}_{2}\right)$ and nitrate $\left(\mathrm{NO}_{3}{ }^{-}\right)$. Atmos. Environ., 41(26), 5502-5509.

Frey, M.M., R.C. Bales and J.R. McConnell. 2007. Climate sensitivity of the century-scale hydrogen peroxide $\left(\mathrm{H}_{2} \mathrm{O}_{2}\right)$ record preserved in 23 ice cores from West Antarctica. J. Geophys. Res., 111(D21), D21301. (10.1029/2005JD006816.)

Frey, M.M. and 6 others. 2009. Contrasting atmospheric boundary layer chemistry of methylhydroperoxide $\left(\mathrm{CH}_{3} \mathrm{OOH}\right)$ and hydrogen peroxide $\left(\mathrm{H}_{2} \mathrm{O}_{2}\right)$ above polar snow. Atmos. Chem. Phys., 9(10), 3261-3276.
Fuhrer, K., A. Neftel, M. Anklin and V. Maggi. 1993. Continuous measurements of hydrogen peroxide, formaldehyde, calcium and ammonium concentrations along the new GRIP ice core from Summit, central Greenland. Atmos. Environ. A, 27(12), 1873-1880.

Gillett, R.W., T.D. van Ommen, A.V. Jackson and G.P. Ayers. 2000. Formaldehyde and peroxide concentrations in Law Dome (Antarctica) firn and ice cores. J. Glaciol., 46(152), 15-19.

Grannas, A.M. and 34 others. 2007. An overview of snow photochemistry: evidence, mechanisms and impacts. Atmos. Chem. Phys., 7(16), 4329-4373.

Hatakeyama, S., K. Murano, F. Sakamaki, H. Mukai, H. Bandow and Y. Komakazi. 2001. Transport of atmospheric pollutants from East Asia. Water, Air, Soil Pollut., 130(1-4), 373-378.

Honoki, H., K. Tsushima and K. Hayakawa. 2001. Inorganic constituents in snow accompanied by winter wind and their origin in the Hokuriku districts. J. Health Sci., 47(6), 559-564.

Honoki, H., K. Watanabe, H. lida, K. Kawada and K. Hayakawa. 2007. Deposition analysis of non sea-salt sulfate and nitrate along to the northwest winter monsoon in Hokuriku district by a snow boring core and bulk samples. Bull. Glaciol.Res., 24, 23-28.

Hutterli, M.A., J.R. McConnell, R.C. Bales and R.W. Stewart. 2003. Sensitivity of hydrogen peroxide $\left(\mathrm{H}_{2} \mathrm{O}_{2}\right)$ and formaldehyde $(\mathrm{HCHO})$ preservation in snow to changing environmental conditions: implications for ice core records. J. Geophys. Res., 108(D1), 4023. (10.1029/2002JD002528.)

lizuka, Y., M. Igarashi, K. Watanabe, K. Kamiyama and O. Watanabe. 2000. Re-distribution of chemical compositions in the snowpack at the dome of Austfonna ice cap, Svalbard. Seppyo, J. Jpn. Soc. Snow Ice, 62(3), 245-254. [In Japanese with English summary.]

lizuka, Y., M. Igarashi, K. Kamiyama, H. Motoyama and O. Watanabe. 2002. Ratios of $\mathrm{Mg}^{2+} / \mathrm{Na}^{+}$in snowpack and an ice core at Austfonna ice cap, Svalbard, as an indicator of seasonal melting. J. Glaciol., 48(162), 452-460.

Jacobi, H.W. and 7 others. 2002. Measurements of hydrogen peroxide and formaldehyde exchange between the atmosphere and surface snow at Summit, Greenland. Atmos. Environ., 36(15-16), 2619-2628.

Kamiyama, K., H. Motoyama, Y. Fujii and O. Watanabe. 1996. Distribution of hydrogen peroxide in surface snow over Antarctic ice sheet. Atmos. Environ., 30(6), 967-972.

Keene, W.C., A.A.P. Pszenny, J.N. Galloway and M.E. Hawley. 1986. Sea-salt corrections and interpretation of constituent ratios in marine precipitation. J. Geophys. Res., 91(D6), 6647-6658.

Kok, G.L., S.E. McClaren and M.H. Staffelbach. 1995. HPLC determination of atmospheric organic hydroperoxides. J. Atmos. Oceanic Technol., 12(2), 282-289.

Kume, A., S. Numata, K. Watanabe, H. Honoki, H. Nakajima and M. Ishida. 2009. Influence of air pollution on the mountain forests along the Tateyama-Kurobe Alpine Route. Ecol. Res., 24(4), 821-830.

Lazrus, A.L., G.L. Kok, J.A. Lind, S.N. Gitlin and S.E. McLaren. 1985. Automated fluorometric method for hydrogen peroxide in atmospheric precipitation. Anal. Chem., 57(4), 917-922.

Lind, J.A. and G.L. Kok. 1994. Correction to 'Henry's law determination for aqueous solutions of hydrogen peroxide, methylhydroperoxide and peroxyacetic acid' by John A. Lind and Gregory L. Kok. J. Geophys. Res., 99(D10), 21,119.

McConnell, J.R., J.R. Winterle, R.C. Bales, A.M. Thompson and R.W. Stewart. 1997. Physically based inversion of surface snow concentrations of $\mathrm{H}_{2} \mathrm{O}_{2}$ to atmospheric concentrations at South Pole. Geophys. Res. Lett., 24(4), 441-444.

McConnell, J.R., R.C. Bales, R.W. Stewart, A.M. Thompson, M.R. Albert and R. Ramos. 1998. Physically based modeling of atmosphere-to-snow-to-firn transfer of $\mathrm{H}_{2} \mathrm{O}_{2}$ at South Pole. J. Geophys. Res., 103(D9), 10,561-10,570.

Motoyama, H. and 9 others. 2001. Regional characteristics of chemical constituents in surface snow, Arctic cryosphere. Polar Meteorol. Glaciol., 15, 55-60. 
Neftel, A., R.C. Bales and D.J. Jacob. 1995. $\mathrm{H}_{2} \mathrm{O}_{2}$ and $\mathrm{HCHO}$ in polar snow and their relation to atmospheric chemistry. In Delmas, R.J., ed. Ice core studies of global biogeochemical cycles. Berlin, etc., Springer-Verlag, 249-264. (NATO ASI Series I: Global Environmental Change 30.)

Noguchi, I. and 9 others. 2007. Temporal trends of non-sea salt sulfate and nitrate in wet deposition in Japan. Water, Air, Soil Pollut.: Focus, 7(1-3), 67-75.

Ohara, T. and 6 others. 2007. An Asian emission inventory of anthropogenic emission sources for the period 1980-2020. Atmos. Chem. Phys., 7(16), 4419-4444.

Osada, K. and 6 others. 2000. Chemical stratigraphy of water soluble constituents in spring snow cover at Murododaira, Tateyama Mts., Japan. Seppyo, J. Jpn. Soc. Snow Ice, 62(1), 3-14. [In Japanese with English summary.]

Osada, K., H. Iida, M. Kido, K. Matsunaga and Y. Iwasaka. 2004. Mineral dust layers in snow at Mount Tateyama, Central Japan: formation processes and characteristics. Tellus, $\mathbf{5 6 B}(4), 382-392$.

Osada, K., T. Ohhara, I. Uno, M. Kido and H. Iida. 2009. Impact of Chinese anthropogenic emissions on submicrometer aerosol concentration at Mt. Tateyama, Japan. Atmos. Chem. Phys., 9(23), 9111-9120.

Sakugawa, H. and I.R. Kaplan. 1989. $\mathrm{H}_{2} \mathrm{O}_{2}$ and $\mathrm{O}_{3}$ in the atmosphere of Los Angeles and its vicinity: factors controlling their formation and their roles as oxidants of $\mathrm{SO}_{2}$. J. Geophys. Res., 94(D10), 12,957-12,973.

Shah, S.K., M. Tanaka, T. Kuramoto and K. Suzuki. 2008. Chemical dynamics of snowpack in the Northern Japan Alps during snowmelt season. Bull. Glaciol. Res., 26, 9-14.

Sigg, A. and A. Neftel. 1988. Seasonal variations in hydrogen peroxide in polar ice cores. Ann. Glaciol., 10, 157-162.

Sigg, A. and A. Neftel. 1991. Evidence for a 50\% increase in $\mathrm{H}_{2} \mathrm{O}_{2}$ over the past 200 years from a Greenland ice core. Nature, 351(6327), 557-559.

Sigg, A., T. Staffelbach and A. Neftel. 1992. Gas phase measurements of hydrogen peroxide in Greenland and their meaning for the interpretation of $\mathrm{H}_{2} \mathrm{O}_{2}$ records in ice cores. J. Atmos. Chem., 14(1-4), 223-232.

Tanimoto, H. 2009. Increase in springtime tropospheric ozone at a mountainous site in Japan for the period 1998-2006. Atmos. Environ., 43(6), 1358-1363.

Tsuruta, H. 1991. Kosa. Tokyo, Nagoya University. Water Research Institute.

Virkkunen, K. and 6 others. 2007. Warm summers and ion concentrations in snow: comparison of present day with Medieval Warm Epoch from snow pits and an ice core from Lomonosovfonna, Svalbard. J. Glaciol., 53(183), 623-634.

Watanabe, K. and H. Honoki. 2003. On the Kosa (Asian dust) event in November 2002: aerosol number concentrations and precipitation chemistry in Toyama, Japan. J. Meteorol. Soc. Jpn, 81(6), 1489-1495.
Watanabe, K. and H. Tanaka. 1995. Measurement of gaseous hydrogen peroxide $\left(\mathrm{H}_{2} \mathrm{O}_{2}\right)$ concentrations in the urban atmosphere. J. Meteorol. Soc. Jpn, 73(5), 839-847.

Watanabe, K., K. Kamiyama, O. Watanabe and K. Satow. 1998. Evidence for an 11-year cycle of atmospheric $\mathrm{H}_{2} \mathrm{O}_{2}$ fluctuation recorded in an ice core at the coastal region, East Antarctica. J. Meteorol. Soc. Jpn, 76(3), 447-457.

Watanabe, K., Y. Ishizaka and C. Takenaka. 1999. Chemical composition of fog water near the summit of Mt. Norikura in Japan. J. Meteorol. Soc. Jpn, 77(5), 997-1006.

Watanabe, K., Y. Ishizaka and C. Takenaka. 2001a. Chemical characteristics of cloud water over the Japan Sea and the Northwestern Pacific Ocean near the central part of Japan: airborne measurements. Atmos. Environ., 35(4), 645-655.

Watanabe, K., Y. Ishizaka, Y. Minami and K. Yoshida. 2001b. Peroxide concentrations in fog water at mountainous sites in Japan. Water, Air, Soil Pollut., 130(1-4), 1559-1564.

Watanabe, K., I. Suzuki and Y. Dokiya. 2005a. Aerosol number concentrations during Kosa events on suburban hills in Japan. Water, Air, Soil Pollut.: Focus, 5(3-6), 195-206.

Watanabe, K., Y. Nojiri and S. Kariya. 2005b. Measurements of ozone concentrations on a commercial vessel in the marine boundary layer over the northern North Pacific Ocean. J. Geophys. Res., 110(D11), D11310. (10.1029/2004JD005514.)

Watanabe, K., A. Iwai, N. Takeda and Y. Takebe. 2005c. Measurements of peroxide concentrations in precipitation in Toyama and in the snow pit at Murododaira, near the summit of Mt. Tateyama. Bull. Glaciol. Res., 22, 51-55.

Watanabe, K., Y. Takebe, N. Sode, Y. Igarashi, H. Takahashi and Y. Dokiya. 2006a. Fog and rainwater chemistry at Mt. Fuji: a case study during the September 2002 campaign. Atmos. Res., 82(3-4), 652-662.

Watanabe, K., H. Honoki, M. Yoshihisa, T. Nishino and Y. Yanase. 2006b. Measurements of ozone nitrogen oxides and sulfur dioxide concentrations at Bijodaira, on the western slope of Mt Tateyama. J. Jpn Soc. Atmos. Environ., 41(5), 268-278. [In Japanese with English summary.]

Watanabe, K., H. Kasuga, Y. Yamada and T. Kawakami. 2006c. Size distributions of aerosol number concentrations and watersoluble constituents in Toyama, Japan: a comparison of the measurements during Asian dust period with non-dust period. Atmos. Res., 82(3-4), 719-727.

Watanabe, K. and 10 others. 2009. Measurements of peroxide concentrations in precipitation and dew water in Toyama, Japan. Bull. Glaciol. Res., 27, 1-5.

Watanabe, K. and 9 others. 2010a. Chemical characteristics of fog water at Mt. Tateyama, near the coast of the Japan Sea in central Japan. Water, Air, Soil Pollut., 211(1-4), 379-393.

Watanabe, K., N. Eda and M. Aoki. 2010b. Observation of trace gases over Toyama Prefecture using a helicopter. Tenki, 57(2), 77-82. [In Japanese.] 